\title{
THE POWER OF THE STATES OVER COM- MODITIES EXCLUDED BY CONGRESS FROM INTERSTATE COMMERCE
}

The Supreme Court of Montana has recently held, ${ }^{1}$ in a case of more than ordinary significance, that a statute forbidding the entrance into the state of women for immoral purposes, and making criminal the aiding or inducing of such entrance, is unconstitutional, since the so-called Mann Act, passed by Congress, is exclusive in its operation and prevents the states from exercising any control over the same subject. Congress has forbidden the transportation in interstate commerce of women for immoral purposes; the state cannot forbid their entrance within its borders. In effect, if not in words, then, State v. Harper holds, as a general principle, that when Congress has prohibited certain subjects of interstate commerce, the states are powerless to interfere with these same subjects, and it would seem to be immaterial that the federal and state laws might act concurrently.

The legislative trend is undeniably toward further exclusions by Congress from interstate commerce, and this doctrine, if valid, may be of far-reaching importance, the most immediate, if not the most obvious, consequence being that the recent WebbKenyon Act, ${ }^{3}$ excluding from interstate commerce certain shipments of liquor, will become a dead letter, since it attaches no penalties. The theory of Congress was that the states would have power over these prohibited shipments, but under State $v$. Harper the local laws would be unconstitutional on the ground that the federal legislation had precluded state interference. It is important, then, to inquire whether this decision is correct, although in doing so we may simply state the obvious. The principle is of sufficient significance, however, to merit reiteration.

\footnotetext{
${ }^{1}$ State v. Harper, 48 Mont. 456, 5I L. R. A. (N. S.) 157 (I914) and note, which says that this "appears to be the only case passing upon the question whether a state statute enacted for the prevention of immorality is unconstitutional as an interference with interstate commerce." Laws of Montana, IgII, p. 3 .

${ }^{2} 36$ Stat. at L. 825.

${ }^{3} 37$ Stat. at L. 699.
} 
The Montana court considered the constitutionality of the state statute according to the classification suggested by the Supreme Court of the United States in Covington \& C. Bridge Co. v. Kentucky:

"The adjudications of this court with respect to the power of the states over the general subject of commerce are divisible into three classes: First, those in which the power of the state is exclusive; second, those in which the states may act in the absence of legislation by Congress; third, those in which the action of Congress is exclusive and the states cannot interfere at all." 4

Upon the basis of this test the Montana court held that the case could not be accepted as one of the first class, in which the state power is exclusive, since the Mann Act had been passed by Congress and declared constitutional. This is certainly true, but the court went on to say that the statute did not fall within the third class, since "it will be admitted without argument . . . that the state under its reserved police power has the right, at least in the absence of congressional legislation, to control the matter of bringing persons into the state, there to engage in immoral practices," and in support of this contention quoted the United States Supreme Court's familiar language in Hoke v. United States:

"There is unquestionably a control in the states over the morals of their citizens, and, it must be admitted, it extends to making prostitution a crime. It is a control, however, which can be exercised only in the jurisdiction of the states; but there is a domain which the states cannot reach and over which Congress alone has power; and if such power be exerted to control what the states cannot, it is an argument for-not against-its legality."

The conclusion of the Montana Court was, therefore, that by elimination, the state statute fell into the second class, and was valid until Congress acted, but thereafter invalid. ${ }^{\circ}$

This, however, is inconclusive reasoning, both in method and result. The language just quoted can well be given a contrary

I54 U. S. 204.

${ }^{8} 227$ U. S. 308.

"It would seem that in a case like this, the "privileges and immunities" section of the fourth article of the federal constitution might be involved, but the Montana court did not advert to it. 
interpretation,- that the state has no power, in the absence of congressional legislation, to prevent the importation of women for immoral purposes, and that for this reason, federal action was necessary. But the real test for state power was given by the United States Supreme Court in Bowman v. Chicago \& Northwestern R. Co. ${ }^{7}$ (not considered in State v. Harper), where it was held that the states may exclude from their borders only articles which are intrinsically unfit for commerce and unmerchantable. The court enumerates, as examples, "rags or other substances infected with the germs of yellow fever, or the virus of small pox, or cattle, or meat or other provisions that are diseased or decayed." These articles "may be rightly outlawed as intrinsically and directly the immediate sources and causes of destruction to human health and life." According to this test, the reasoning of the Montana court is clearly false. It is extremely doubtful whether before the Mann Act the states could have kept out women who intended to-engage in immoral practices. The exclusiveness of federal authority in respect to commodities which have been prohibited from interstate commerce, is thus not justified and remains a point primce impressionis. ${ }^{8}$

In any event it would seem that the question as to the power of the states before congressional action is material only when the commodities prohibited by federal law come within the test laid down by the Supreme Court of the United States in the Bozeman Case, and that an additional denunciation of these commodities by Congress would certainly not have the effect of depriving the states of power which they already possessed. The problem is slightly different when the states have no authority to exclude, but here it is logical to maintain that when Congress has acted and inhibited certain commodities which thereafter are not properly subjects of interstate commerce, the states, by legislation to the same effect, or by supplementary police regulations, cannot unconstitutionally interfere with interstate commerce, since Congress has decreed that there may be no commerce in these prohibited commodities.

This is the theory of the Webb-Kenyon Act, which forbids the interstate transportation of intoxicating liquor when it is

\footnotetext{
T I27 U. S. 465 .

${ }^{8}$ See, however, Rupert v. U. S., I8I Fed. 87, and Sec. 242, Criminal Code, March 4, Ig0g.
} 
intended to be used, sold, or possessed in violation of an independently valid law of the state of destination. The purpose of the statute, as expressed in its title, is to divest "intoxicating liquors of their interstate character in certain cases," with the result, not, it is true, expressed in the act, but nevertheless desired by Congress, that the states may interfere with these unlawful shipments while they are actually, although not properly, in interstate commerce. Thus, if a state forbids the possession of more than a certain quantity of liquors, ${ }^{\circ}$ all shipments in excess of this amount will be with intent to violate a state law, and can be seized and destroyed before reaching the consignee. Or, if the liquors are intended to be sold, contrary to valid local regulations, they may be seized and destroyed..$^{10}$

The almost unanimous weight of authority, ${ }^{11}$ before adjudication by the United States Supreme Court, is that it was competent for Congress, thus, indirectly, but by a positive prohibition, to enlarge the powers of the states, and to permit them, by supplementary legislation, to make the Webb-Kenyon Act effective. Where the language of a statute is clear, its title cannot change its effect, ${ }^{12}$ and the Webb-Kenyon Act's declared purpose,- to divest intoxicating liquors of their interstate character in certain cases,-is not sufficient basis for giving it an interpretation and scope different from that given positive prohibitions of interstate commerce, with different titles, and complete in that for their execution no state action is necessary. The effect of an exclusion from interstate commerce must be the same in either event, and, therefore, those who would hold the Webb-Kenyon Act constitutional, must accept this more general proposition, upon which the act was based: When Congress has excluded certain

${ }^{9}$ Alabama is, I believe, the first state to do this. Act of January 27, IgI5, sec. I2.

${ }^{10}$ As to the theory upon which the Webb-Kenyon Act is expected to operate, and its constitutional justification, see "Brief on the so-called Kenyon Interstate Liquor Bill," 62d Cong., 3d Sess., Sen. Doc. I060; argument of F. S. Caldwell, Hearings before a Subcommittee of the Committee on the Judiciary, U. S. Senate, 62d Cong., ad Sess., pp. I30 ff, reprinted as Senate Document, 488, 62d Cong., 2d Sess.; my papers, "The Constitutionality of the Webb-Kenyon Bill," I Cal. I. Rev. 499, and "State Legislation under the Webb-Kenyon Act," 28 Harv. L. Rev. 225, and the case note, 28 Harv. L. Rev. 432.

${ }^{11}$ State v. Grier, $88 \mathrm{Atl}$. (Del.) 579; State v. U. S. Express Co., I45

$N$. W. (Iowa) $45 \mathrm{I}$, and other cases there referred to.

${ }^{12} 26$ Amer. \& Eng. Encyc. of Law, 629. 
commodities from interstate commerce the protection of interstate commerce is taken away from these commodities and the authority of the state can attach to them while they are in transit to the extent of forbidding them entrance to the state if this is the effect of the federal law. There is no reason why the transportation in interstate commerce and the introduction into the state may not be two distinct crimes against two governments. ${ }^{13}$ If this theory is correct, the Montana law excluding from the state women intended for immoral purposes, is valid, and the decision in State $v$. Carter is wrong.

It should be pointed out, however, that this conclusion is by no means dependent upon the validity of the Webb-Kenyon Act, which has simply been used for purposes of illustration and to show the dangerous consequences of the Montana court's decision. Objection has been made to the Webb-Kenyon Act on the ground that Congress has no power to exclude on account of the intent with which commodities are being transported, when this intent is legal or illegal according to the local regulations of forty-eight jurisdictions. This, if true, would not affect my proposition, for Congress certainly has authority to exclude from interstate commerce all intoxicating liquor, and if this were done, state prohibition legislation would not interfere with the federal commercial power since there could be no legitimate interstate trade in liquors.

To illustrate the general contention here made, take the case of lottery tickets. Congress has prohibited them from interstate commerce $^{14}$; Maryland has made it a crime to bring any lottery ticket into the state. ${ }^{15}$ Is this provision unconstitutional? If the federal authorities do not detect violations of the law, and the state does, is the latter powerless to punish? Or, further, the Maryland law forbids any person to "have in his possession in this state, any book, slip, or record of the numbers drawn in any lottery." Is the state powerless to enforce this inhibition against a carrier in possession of lottery tickets before they have reached the consignee? If it desires, is it powerless to seize the tickets and destroy them before their interstate journey is completed?

${ }^{13}$ Coleman v. Tennessee, 97 U. S. 509; Cross v. North Carolina, I32 U. S. I3I, and cases cited.

"Champion v. Ames, I88 U. S. $32 \mathrm{I}$.

${ }^{15}$ Maryland Code of Public General Laws, Art. 27, sec. 283. See also Ford v. State, 85 Md. 474 and Bullock v. State, 73 Md. 2. 
The state has the power in each case ${ }_{;}^{18}$ otherwise it would be possible for one to plead a violation of federal law as immunity from punishment under a state law, and this would be a contention similar to that which the United States Supreme Court, in upholding the Mann Act, considered a "supreme fallacy," since it urged "a right to be exercised in morality to sustain a right to be exercised in immorality." The Court went on to say:

". . it must be kept in mind that we are one people; and the powers reserved to the states and those conferred on the nation are adapted to be exercised, whether independently or concurrently, to promote the general welfare, material and moral. This is the effect of the decisions; and surely if the facility of interstate transportation can be taken away from the demoralization of lotteries, the debasement of obscene literature, and the contagion of diseased cattle, or persons, the impurity of food and drugs, the like facility can be taken away from the systematic enticement to and the enslavement in prostitution and debauchery of women, and more insistently, of girls."17

When Congress has taken this facility from particular commodities, it is certainly logical and reasonable to hold that the protection of interstate commerce is thereby taken away, and that a right exercised in morality cannot become a right to be exercised in immorality, and hence make unconstitutional state legislation applying to these particular commodities actually, although not properly, in interstate commerce.

LINDSAY ROGERS.

JOHNS HOPKINS UNIVERSITY.

${ }^{16}$ Not, of course, if one accepts the ruling of State $v$. Harper.

${ }^{17}$ Hoke v. United States, supra. 